Reprod. Nutr. Dévelop., 1988, 28 (5), 1275-1282

\title{
Characterization and hormonal regulation of tissue and fluid proteins in the mouse epididymis
}

\author{
J. R. MBOUNGOU, Henriette, Roberte JUNERA, J. P. DADOUNE, Marcelle- \\ Anne FAIN-MAUREL \\ Groupe d'Etude de la Formation et de la Maturation du Gamète Mâle \\ (Laboratoires de Biologie Cellulaire et d'Histologie). \\ 45, rue des Saints-Pères, 75270 Paris Cedex 06, France.
}

Summary. The proteins of epididymal tissues and fluids recovered from different regions of the mouse epididymis from a natural population and an inbred line were examined by polyacrylamide gel electrophoresis under denaturing conditions. Two epididymal specific peptides on the order of 88 and 20 Kilodaltons (Kd), undetected in serum and testicular extracts, were identified in the initial segment, caput, corpus and cauda. Another specific $30 \mathrm{Kd}$ peptide was localized in the cauda tissue and fluid. Castration caused the disappearance of the three specific epididymal bands and of a non-specific $34 \mathrm{Kd}$ band. In contrast, a new band appeared at $14.5 \mathrm{Kd}$. Testosterone propionate administration only restored the three specific epididymal bands and had no effect on the 14.5 peptide. Variations in the staining intensity of the four bands, which were suppressed in castrated animals, were observed after ductuli efferentes ligation.

\section{Introduction.}

It is now recognized that epididymis provides a suitable environment for sperm maturation and that epididymal secretory proteins interact with the spermatozoa suspended in the fluid. Although it is known that this epididymal environment is regulated by androgenic hormones, less attention has been focused on the mechanisms of androgen action. This is probably due to the fact that the epididymis is a complex organ with regional variations, and that androgens reach the epithelium by two routes, via luminal fluid from the rete testis and conventionally via the circulatory system (for a review, see Cooper, 1986).

Identification of androgen-responsive proteins in epididymal fluid has been performed by electrophoresis in the rat (Brooks and Higgins, 1980 ; Jones et al., 1980 ; Brooks, $1981 ; 1983$ ), the rabbit (Jones et al., 1981), the monkey (Arslan et al., 1986) and man (Tezón et al., 1985), but in the mouse, only 15 to 20 cauda luminal peptides have been detected without any mention of their androgen-

Reprint request to Prof. M-A. Fain-Maurel. 
dependence (Flickinger et al., 1986). Although radioautographic studies have evidenced the pathway and kinetics of protein secretion in the various segments of the mouse epididymis (Fain-Maurel et al., 1981 ; Flickinger, 1981), the nature of the proteins involved and their differential response to androgen are not known. Thus, the present investigation was carried out (1) to characterize epididymal proteins from tissues and fluids by sodium dodecyl sulfate polyacrylamide gel electrophoresis, (2) to assess the effect of androgens on protein synthesis in the four parts of the epididymis of natural and inbred mouse populations.

\section{Materials and methods.}

Adult male Swiss OF1 (natural population) mice (2-3 months) weighing 30-40 g and control adult mice C57BL (inbred line) were used for this work.

Swiss OF1 mice were subdivided into four groups: group l) untreated animals; group II) castrated for 4 weeks; group III) castrated for 4 weeks followed by testosterone propionate administration $(0.56 \mathrm{mg}$ in $0.2 \mathrm{ml}$ of olive oil ; 3 times per week) for 4 weeks; group IV) after bilateral efferentes ductuli ligation for 4 weeks.

Preparation of samples. - The animals were anaesthetized with chloral hydrate and the vascular system was perfused with $0.9 \% \mathrm{NaCl}$ to clear the reproductive organs of blood. The epididymides were quickly removed, dissected and subdivided into four regions (initial segment, caput, corpus and cauda). Tissues, kept over ice, were weighed, chopped finely at $32{ }^{\circ} \mathrm{C}$ in a phosphate buffer saline solution ( $\mathrm{pH} 7.6$ ) containing protease inhibitors ( $1 \%$ Zymofren, $0.2 \mathrm{mM} \mathrm{PMSF}$ ) and $4 \mathrm{mM}$ EDTA. Epididymal luminal fluids were expressed and sperm was separated from epididymal fluid by centrifugation. Sperm-free tissues were homogenized in the same buffer with $0.2 \%$ Triton X100. After centrifugation of epididymal fluids and homogenates at $50000 \mathrm{~g}\left(2 \times 30 \mathrm{~min}, 4^{\circ} \mathrm{C}\right)$ the samples were stored at $-30^{\circ} \mathrm{C}$ until analysis. In some experiments, caput, corpus and cauda fluids, isolated by ligatures, were obtained by micropuncture and treated similarly. Protein content was determined by the Bradford method (1976) with bovine serum albumin as the standard protein.

Polyacrylamide gel electrophoresis (SDS-PAGE). - Aliquots containing $50 \mu \mathrm{g}$ of protein were mixed by dilution $(\mathrm{v} / \mathrm{v})$ with Laemmli buffer $(0.0125 \mathrm{M}$ Tris ; $4 \%$ SDS ; $0.001 \%$ Bromophenol blue; $20 \%$ glycerol; $5 \% \beta$-mercaptoethanol; $\mathrm{pH}$ 6.8) followed by boiling for $3 \mathrm{~min}$. The samples were loaded on $11 \%$ SDS-polyacrylamide mini-gels $(8 \mathrm{~cm} \times 8 \mathrm{~cm} \times 0.075 \mathrm{~cm})$ or $15 \%$ SDSpolyacrylamide gels $(13 \mathrm{~cm}$ long) with $5 \%$ stacking gel. First and second gels were run respectively at 120 volts $(2-2.5 \mathrm{~h})$ and 150 volts (5-6 h) in Tris-glycine buffer $\mathrm{pH}$ 8.3. Low molecular weight standard proteins purchased from Pharmacia were also run to calibrate each gel and blue Coomassie dye was used.

\section{Results.}

The electrophoretic patterns obtained from the initial segment, caput, corpus and cauda of the epididymis in the natural (Swiss OF1) and inbred (C57BL) 
mouse populations were similar. No significant differences were found in patterns from expressed or micropuncture fluids.

Separation of soluble proteins from homogenates and fluids of the four epididymal segments revealed the presence of approximately 70 polypeptides ranging in size from 200 to $10 \mathrm{Kd}$, with a greater number in the tissues than in the fluids. When compared to components of mouse serum and testis, three epididymal bands were not matched by comparable bands in serum and testis samples. These included the peptides on the order of 88,30 and $20 \mathrm{Kd}$. The 88 and $20 \mathrm{Kd}$ peptides were present in the four segments, the former being more visible in the proximal part (initial segment, caput) of the epididymis, the latter in medial and distal parts. Protein $30 \mathrm{Kd}$ appeared to be specific to the cauda tissues and fluids (fig. 1). Moreover, eight bands (45, 43, 34, 31.5, 26.5, 20.5, 19 and $13 \mathrm{Kd}$ ), which comigrated with serum and/or testis components, showed noticeable regional variations of staining intensity and appeared more intensely stained in fluids than tissues (table 1).

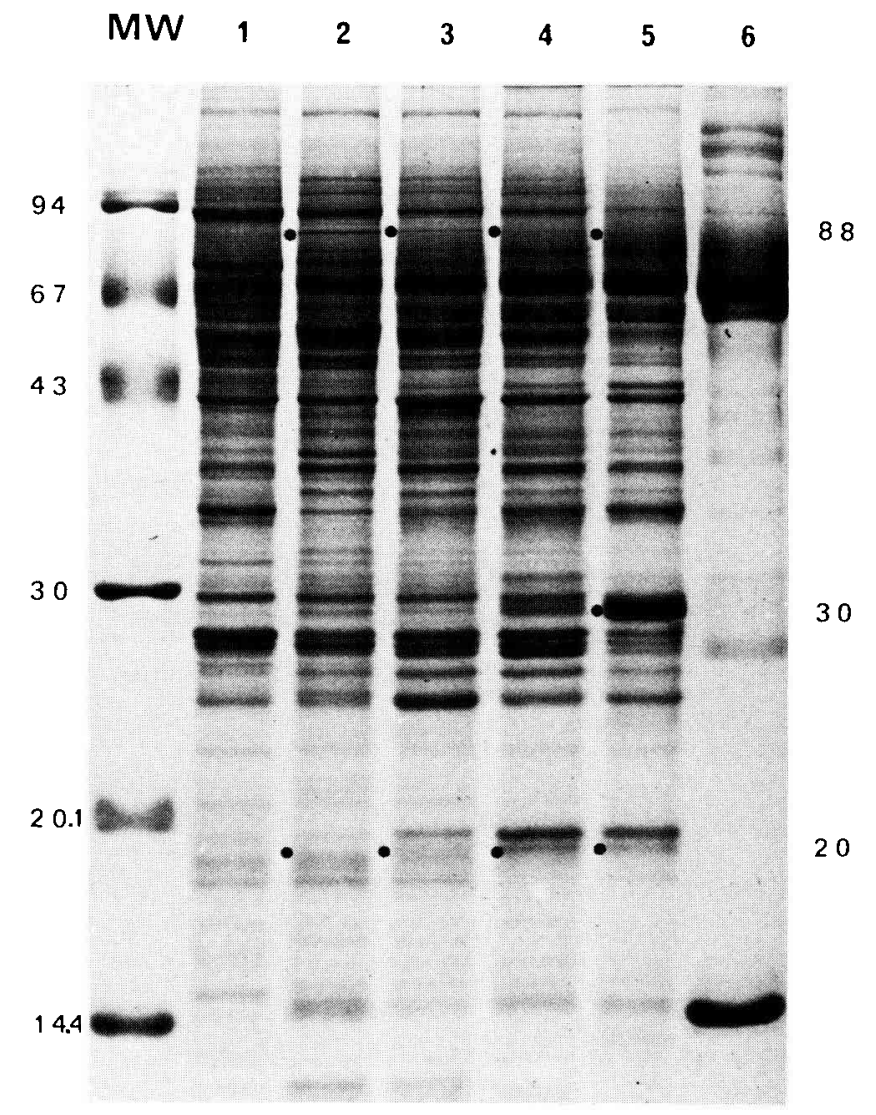

FIG. 1. - SDS-PAGE (15\%) of molecular weight standards (MW), testicular (lane 1), initial segment (lane 2), caput (lane 3), corpus (lane 4), cauda (lane 5) fluids and blood serum (lane 6) of untreated animals (Swiss OF1). 


\section{TABLE 1}

Regional changes in the staining intensity of proteins (Kd molecular weights) in luminal fluids obtained from different segments of the epididymis and analysed by SDS-PAGE.

\begin{tabular}{cc}
\hline Luminal fluid & \\
\hline Increase & Decrease \\
\hline & 45 \\
43 & \\
« $31.5 »$ & 26.5 \\
20.5 & 19 \\
& 13 \\
\hline
\end{tabular}

Where obvious regional changes in staining intensity of particular bands were observed, they were subjectively scored in terms of an increase or a decrease relative to that observed in the initial segment. 《»: increase in the corpus alone.

Following castration, the specific epididymal 30 and $20 \mathrm{Kd}$ proteins disappeared in tissues and fluids, and the $88 \mathrm{Kd}$ only in fluids. A regional band at $34 \mathrm{Kd}$ was also absent, whereas a new band appeared at $14.5 \mathrm{Kd}$ (fig. 2, table 2). Concomitantly, there was reduced intensity of some components $(31.5,26.5$, 20.5, 19 and $13 \mathrm{Kd}$ ) (fig. 2).

TABLE 2

Presence $(+)$, absence $(-)$ of bands, or bands with either variable width or staining intensity $( \pm)$ in luminal fluids of untreated, castrated, castrated followed by testosterone rep/acement and ligated efferent ducts animals.

Initial segment (IS), caput (H), corpus (B) and cauda (T) fluids of the epididymis.

\begin{tabular}{|c|c|c|c|c|c|c|c|c|c|c|c|c|c|c|c|c|}
\hline \multirow[b]{2}{*}{$\mathrm{MW}(\mathrm{Kd})$} & \multicolumn{4}{|c|}{ Untreated } & \multicolumn{4}{|c|}{ Castrated } & \multicolumn{4}{|c|}{$\begin{array}{c}\text { Castrated } \\
\text { and } \\
\text { treated }\end{array}$} & \multicolumn{4}{|c|}{$\begin{array}{l}\text { Ligated } \\
\text { efferent } \\
\text { ducts }\end{array}$} \\
\hline & IS & $\mathrm{H}$ & B & $\mathrm{T}$ & IS & $\mathrm{H}$ & B & $\mathrm{T}$ & IS & $\mathrm{H}$ & B & $\mathrm{T}$ & IS & $\mathrm{H}$ & B & $\mathrm{T}$ \\
\hline 88 & + & + & \pm & \pm & - & - & - & - & \pm & \pm & \pm & \pm & \pm & \pm & \pm & \pm \\
\hline 34 & \pm & \pm & \pm & \pm & - & - & - & - & - & $\overline{-}$ & $\overline{-}$ & $\bar{z}$ & $\overline{ \pm}$ & \pm & \pm & \pm \\
\hline 30 & $\overline{-}$ & $\bar{z}$ & $\overline{-}$ & $\bar{t}$ & - & - & - & - & - & - & - & + & $\overline{-}$ & $=$ & $\overline{-}$ & + \\
\hline 20 & \pm & \pm & + & + & - & - & - & - & \pm & \pm & \pm & \pm & \pm & \pm & \pm & \pm \\
\hline 14.5 & $\overline{-}$ & \pm & - & - & \pm & \pm & + & + & t & $\bar{t}$ & $\bar{t}$ & $\bar{t}$ & $\bar{z}$ & - & $=$ & $=$ \\
\hline
\end{tabular}

Administration of testosterone propionate stimulated synthesis and secretion of the three specific epididymal peptides $(88,30$ and $20 \mathrm{Kd})$ in tissues and fluids. In contrast, the $34 \mathrm{Kd}$ peptide was not restored and the $14.5 \mathrm{Kd}$ peptide induced by castration persisted despite the hormonal supplementation (fig. 3, table 2). 


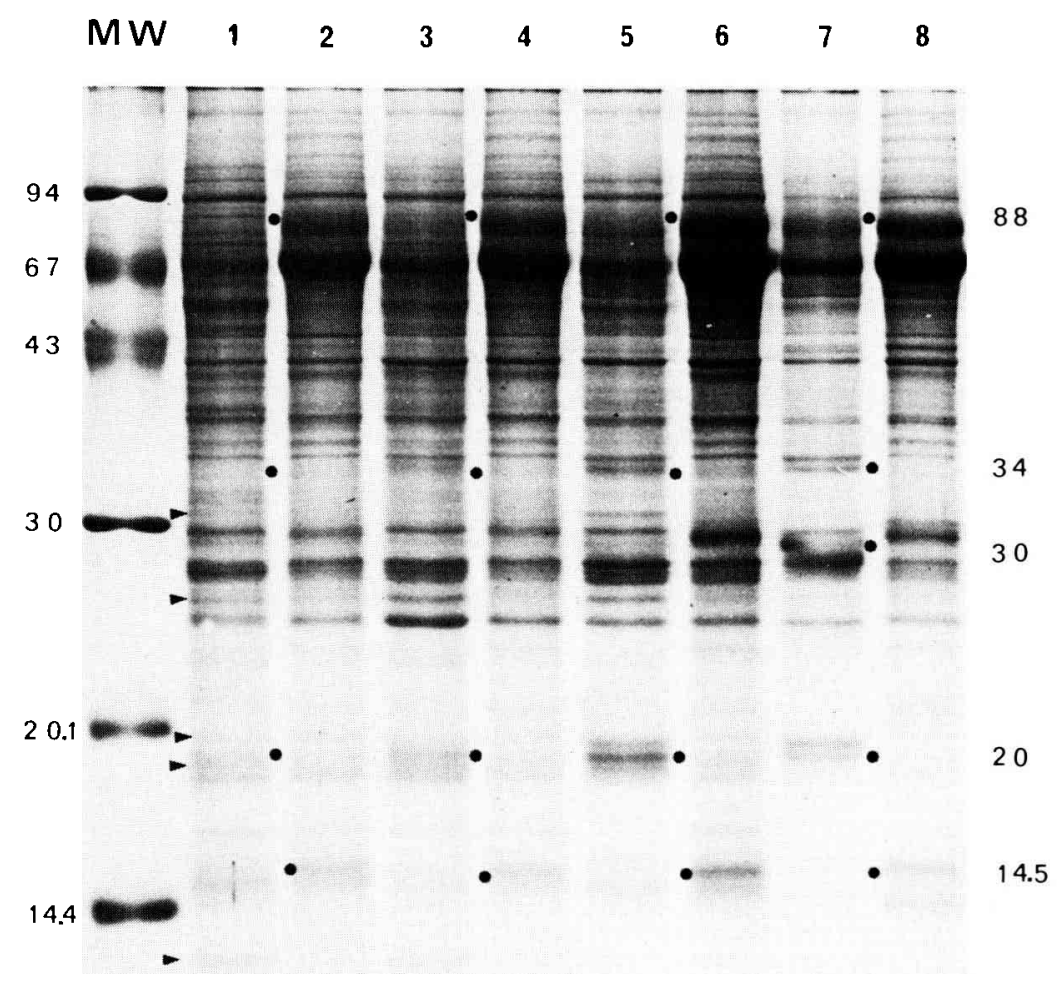

FIG. 2. - SDS-PAGE (15\%) of molecular weight standards (MW), initial segment (lanes 1-2), caput (lanes 3-4), corpus (lanes 5-6) and cauda (lanes 7-8) fluids in untreated (lanes 1-3-5-7) and castrated (lanes 2-4-6-8) animals (Swiss OF1).

The ductuli efferentes ligation had relatively little influence on the electrophoretic patterns. But, when compared to untreated animals, the ligation of the efferent ducts resulted in a decrease in the staining intensity of the 88,34 and $20 \mathrm{Kd}$ peptides, which were affected by castration, and caused an intensity increase of the cauda luminal band at $30 \mathrm{Kd}$.

\section{Discussion.}

In mouse epididymis, the soluble protein composition of homogenates and fluids, revealed by SDS-PAGE, appears relatively complex since the 70 polypeptides identified varied with the different segments of the duct.

Several epididymal proteins were seen in testicular extracts and serum but three peptides appeared epididymis-specific, two $(88$ and $20 \mathrm{Kd})$ throughout the entire length of the duct and one $(30 \mathrm{Kd})$ in the cauda alone. Among these peptides, component $20 \mathrm{Kd}$ could be assimilated to the one having the same 


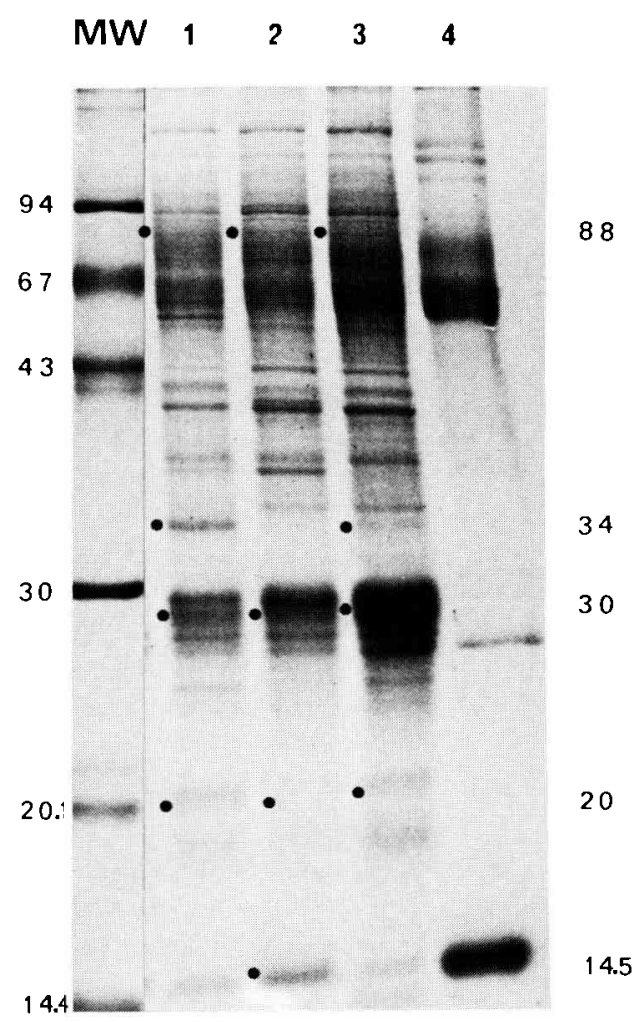

FIG. 3. - SDS-PAGE (15\%) of molecular weight standards (SW), cauda fluids in untreated (lane 1), castrated and treated with testosterone (lane 2) and after ligation of the ductuli efferentes (lane 3) animals (Swiss OF1)

molecular weight found in the rat (Brooks and Higgins, 1980) and the ram (Dacheux and Voglmayr, 1983) because of its expression in all the epididymal segments. The $30 \mathrm{Kd}$ peptide most likely corresponds to the one previously designated CP 27 (27 Kd) (Flickinger et al., 1986) in the mouse cauda epididymis since the methodology was not strictly identical. A major protein with an apparent molecular weight of $27 \mathrm{Kd}$ has also been detected in the rat (Olson and Orgebin-Crist, 1982) and the chimpanzee (Young et al., 1987); note that this protein was evidenced in the cauda fluid and cauda sperm of these species. The most noticeable features affecting regional differences concerned the caudaspecific protein $(30 \mathrm{Kd})$ and the initial segment prominent bands at $45,26.5$ and $19 \mathrm{Kd}$.

As in other species, a small number of cytosol and luminal proteins appeared to be regulated by testosterone (Shabanowitz and Killian, 1987). Of the five proteins whose synthesis was hormonally regulated, three $(88,30$ and $20 \mathrm{Kd})$ were androgen-dependent. In contrast, the $34 \mathrm{Kd}$ polypeptide which was not restored by testosterone-treatment after castration might be controlled by testicular factors since its intensity decreased drastically after ductuli efferentes 
ligation. The inability of exogeneous testosterone to entirely restore the staining intensity of the 88 and $20 \mathrm{Kd}$ bands or to initiate the synthesis of the $34 \mathrm{Kd}$ protein could be related to the dependence of the epididymal epithelium either on high levels of testosterone or conjugated factors in the testicular fluid.

As regards the $14.5 \mathrm{Kd}$ component, which arose after castration and persisted despite androgen therapy, it is likely that androgens inhibit the corresponding gene expression.

$5^{*}$ Congrès de la Société d'Andrologie de langue française, Paris, décembre 1987

Résumé. Caractérisation et régulation hormonale des protéines tissulaires luminales de l'épididyme de souris.

La caractérisation des protéines tissulaires et luminales des différentes régions de l'épididyme de souris a été effectuée par électrophorèse en conditions dénaturantes à partir d'une population naturelle et d'une lignée génétiquement fixée. Deux peptides épididymaires ( 88 et $20 \mathrm{Kd}$ ), non détectés dans le sérum et les extraits testiculaires, ont été identifiés dans le segment initial, la tête, le corps et la queue de l'épididyme. Un autre peptide spécifique de l'épididyme $(30 \mathrm{Kd})$ s'est avéré caractéristique des tissus et des fluides de la queue.

La castration a entraîné la disparition des trois bandes correspondant aux peptides spécifiques de l'épididyme et d'une autre bande $(34 \mathrm{Kd})$. Elle a également provoqué l'expression d'un nouveau peptide $(14,5 \mathrm{Kd})$. L'administration de propionate de testostérone n'a restauré la synthèse et la sécrétion que des trois peptides spécifiques de l'épididyme $(88,20$ et $30 \mathrm{Kd}$ ), restant sans effet sur l'expression du peptide $14,5 \mathrm{Kd}$. La ligature des canaux efférents a affecté l'intensité de la coloration des quatre bandes supprimées par la castration.

\section{References}

ARSLAN M., HAIDER M. Z., QAZI M. H., 1986. Characterization and androgen dependence of specific proteins in the epididymis of adult rhesus monkey. Arch. Androl., 16, 67-74.

BRADFORD M. M., 1976. A rapid and sensitive method for the quantitation of microgram quantities of protein utilizing the principle of protein-dye-binding. Anal. Biochem., 72, 246-254

BROOKS D. E., 1981. Secretion of proteins and glycoproteins by the rat epididymis: regional differences, androgen-dependence, and effects of protease inhibitors, procain, and tunicamycin. Biol. Reprod., 25, 1099-1117.

BROOKS D. E., 1983. Effect of androgens on protein synthesis and secretion in various regions of the rat epididymis, as analysed by two-dimensional gel electrophoresis. Mol. cell. Endocrinol., 29, 255-270.

BROOKS D. E., HIGGINS S. J., 1980. Characterization and androgen-dependence of proteins associated with luminal fluid and spermatozoa in the rat epididymis. J. Reprod. Fert., 59. 363-375.

COOPER T. G., 1986. The epididymis, sperm maturation and fertilisation. Springer-Verlag.

DACHEUX J. L., VOGLMAYR J. K., 1983. Sequence of sperm cell surface differentiation and its relationship to exogenous fluid proteins in the ram epididymis. Biol. Reprod., 29, 1033-1046.

FAIN-MAUREL M. A., DADOUNE J. P., ALPHONSI M. F., 1981. High-resolution autoradiography of newly formed proteins in the epididymis after incorporation of tritiated amino acids. Arch. Androl., 6, 249-266. 
FLICKINGER C. J., 1981. Regional difference in synthesis, intracellular transport, and secretion of protein in the mouse epididymis. Biol. Reprod., 25, 871-883.

FLICKINGER C. J., HERR J. C., ERTL K. E., 1986. Identification and isolation of epididymal luminal proteins of the mouse epididymis. J. Androl., 7, 163-168.

JONES R., BROWN C. R., von GLOS K. I., PARKER M. G., 1980. Hormonal regulation of protein synthesis in the rat epididymis : characterisation of androgen-dependent and testicular fluid proteins. Biochem. J., 188, 667-676.

JONES R., von GLOS K. I., BROWN C. R., 1981. Characterization of hormonally regulated proteins from the caput epididymis of the rabbit. Biochem. J., 196, 105-114.

LAEMMLI U. K., 1970. Cleavage of structural proteins during the assembly of the head of bacteriophage $T_{4}$. Nature, 277, 680-685.

OLSON G. E., ORGEBIN-CRIST M. C., 1982. Sperm surface changes during epididymal maturation. Ann. N.Y. Acad. Sci., 288, 372-391.

SHABANOWITZ R. B., KILLIAN G. J., 1987. Two dimensional electrophoresis of proteins in principal cells, spermatozoa and fluid associated with the rat epididymis. Biol. Reprod., 36. $753-768$.

TEZON J. G., VAZQUEZ M. H., PIÑEIRO L., de LARMINAT M. A., BLAQUIER J. A., 1985. Identification of androgen-induced proteins in human epididymis. Biol. Reprod., 32, 584-590.

YOUNG L. G., GOULD K. G., HINTON B. T., 1987. Changes in binding of a 27-Kilodalton chimpanzee cauda epididymal protein glycoprotein component to chimpanzee sperm. Gamete Res., 18, 163-178. 